\title{
Effect of the sodium reduction and smoking system on quality and safety of smoked salmon (Salmo salar)
}

Muñoz, Israel; Guàrdia, Maria Dolors; Arnau, Jacint; Dalgaard, Paw; Bover, Sara; Fernandes, José O.; Monteiro, Carolina; Cunha, Sara C.; Gonçalves, Amparo; Nunes, Maria Leonor

Total number of authors:

11

Published in:

Food and Chemical Toxicology

Link to article, DOI:

10.1016/j.fct.2020.111554

Publication date:

2020

Document Version

Peer reviewed version

Link back to DTU Orbit

Citation (APA):

Muñoz, I., Guàrdia, M. D., Arnau, J., Dalgaard, P., Bover, S., Fernandes, J. O., Monteiro, C., Cunha, S. C., Gonçalves, A., Nunes, M. L., \& Oliveira, H. (2020). Effect of the sodium reduction and smoking system on quality and safety of smoked salmon (Salmo salar). Food and Chemical Toxicology, 143, [111554].

https://doi.org/10.1016/j.fct.2020.111554

\section{General rights}

Copyright and moral rights for the publications made accessible in the public portal are retained by the authors and/or other copyright owners and it is a condition of accessing publications that users recognise and abide by the legal requirements associated with these rights.

- Users may download and print one copy of any publication from the public portal for the purpose of private study or research.

- You may not further distribute the material or use it for any profit-making activity or commercial gain

- You may freely distribute the URL identifying the publication in the public portal 


\section{Journal Pre-proof}

Effect of the sodium reduction and smoking system on quality and safety of smoked salmon (Salmo salar).

Israel Muñoz, Maria Dolors Guàrdia, Jacint Arnau, Paw Dalgaard, Sara Bover, José O. Fernandes, Carolina Monteiro, Sara C. Cunha, Amparo Gonçalves, Maria Leonor

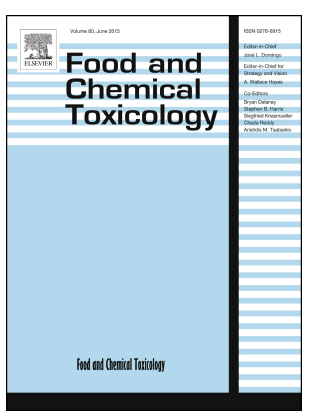
Nunes, Helena Oliveira

PII:

S0278-6915(20)30444-0

DOI:

https://doi.org/10.1016/j.fct.2020.111554

Reference: $\quad$ FCT 111554

To appear in: Food and Chemical Toxicology

Received Date: 26 February 2020

Revised Date: 5 June 2020

Accepted Date: 22 June 2020

Please cite this article as: Muñoz, I., Guàrdia, M.D., Arnau, J., Dalgaard, P., Bover, S., Fernandes, J.O., Monteiro, C., Cunha, S.C., Gonçalves, A., Nunes, M.L., Oliveira, H., Effect of the sodium reduction and smoking system on quality and safety of smoked salmon (Salmo salar)., Food and Chemical Toxicology, https://doi.org/10.1016/j.fct.2020.111554.

This is a PDF file of an article that has undergone enhancements after acceptance, such as the addition of a cover page and metadata, and formatting for readability, but it is not yet the definitive version of record. This version will undergo additional copyediting, typesetting and review before it is published in its final form, but we are providing this version to give early visibility of the article. Please note that, during the production process, errors may be discovered which could affect the content, and all legal disclaimers that apply to the journal pertain.

(c) 2020 Elsevier Ltd. All rights reserved. 
Israel Muñoz ${ }^{1}$, Maria Dolors Guàrdia ${ }^{1 *}$, Jacint Arnau ${ }^{1}$, Paw Dalgaard ${ }^{2}$, Sara Bover ${ }^{3}$, José O. Fernandes ${ }^{4}$, Carolina Monteiro ${ }^{4}$, Sara C. Cunha ${ }^{4}$, Amparo Gonçalves ${ }^{5,6}$, Maria Leonor Nunes ${ }^{6}$, Helena Oliveira ${ }^{5,6}$

${ }^{1}$ IRTA-Food Technology Programme, Finca Camps i Armet, E-17121 Monells, Girona, Spain

${ }^{2}$ National Food Institute, Technical University of Denmark, Lyngby, Denmark

${ }^{3}$ IRTA-Food Safety Programme, Finca Camps i Armet, E-17121 Monells, Girona, Spain

${ }^{4} L A Q V$, REQUIMTE, Departamento de Ciências Químicas, Laboratório de Bromatologia e Hidrologia, Faculdade de Farmácia, Universidade do Porto, Porto, Portugal

${ }^{5}$ IPMA, I.P., Portuguese Institute for the Sea and Atmosphere, Division of Aquaculture and Upgrading, Av. Alfredo Magalhães Ramalho 6, 1495-165 Lisboa, Portugal

${ }^{6}$ CIIMAR, Interdisciplinary Centre of Marine and Environmental Research, University of Porto, Terminal de Cruzeiros do Porto de Leixões, Av. General Norton de Matos S/N, 4450-208 Matosinhos, Portugal

* Corresponding author. E-mail address: maria.dolors@irta.cat (Maria Dolors Guàrdia Gasull)

Israel Muñoz: Investigation, Writing - Original Draft

Maria Dolors Guàrdia: Conceptualization, Methodology, Supervision, Investigation, Writing - Original Draft

Jacint Arnau: Conceptualization, Methodology, Writing- Original draft, Visualization, Investigation

Paw Dalgaard: Software, Writing - Review \& Editing.

Sara Bover: Methodology, Formal Analysis, Writing - Review and editing

Jose O. Fernandes: Investigation

Carolina Monteiro: Investigation

Sara C. Cunha: Investigation, Writing - Review \& Editing

Amparo Gonçalves - Investigation, Writing - Review \& Editing

Maria Leonor Nunes - Writing - Review \& Editing, Project administration, Funding acquisition

Helena Oliveira - Investigation, Writing - Review \& Editing, Project administration 


\section{Abstract}

Excessive sodium ( $\mathrm{Na}$ ) intake has been associated with high blood pressure and cardiovascular diseases. Therefore, sodium reduction is a public health challenge worldwide. The aim of this study was to develop smoked salmon with a reduced $\mathrm{Na}$ content. Sodium chloride $(\mathrm{NaCl})$ was replaced by potassium chloride $(\mathrm{KCl})$ at $25 \%$ and $50 \%$ (molar replacement) and studied in combination with two smoking procedures (natural wood and liquid smoke) as well as two smoking temperatures (18-19ㅇ or 56 C). Smoked salmon samples were characterized by physicochemical, sensory and microbiological analyses. No major differences were observed regarding physicochemical properties in the studied treatments. Smoked samples with $50 \%$ of $\mathrm{NaCl}$ replaced by $\mathrm{KCl}$ were slightly more bitter than those with $25 \%$ whereas samples with $25 \%$ of replacement did not show differences to those with non-reduced $\mathrm{Na}$ content ( $5 \mathrm{~g}$ of added $\mathrm{NaCl}$ per $100 \mathrm{~g}$ of salmon). Microbiological assessment indicates that 2-week shelf-life would be appropriate and safe in terms of accomplishment of the EU regulation, taking into account foreseeable storage temperatures (up to $8 \circ \mathrm{C}$ ). Thus, it is possible to achieve a reduction of $25-50 \%$ of $\mathrm{NaCl}$ in smoked salmon by replacing $\mathrm{NaCl}$ by $\mathrm{KCl}$ and considerer this product as a "source" of $\mathrm{K}$. 
Effect of the sodium reduction and smoking system on quality and safety of smoked salmon (Salmo salar).

Israel Muñoz ${ }^{1}$, Maria Dolors Guàrdia ${ }^{1 *}$, Jacint Arnau ${ }^{1}$, Paw Dalgaard ${ }^{2}$, Sara Bover ${ }^{3}$, José O. Fernandes ${ }^{4}$, Carolina Monteiro ${ }^{4}$, Sara C. Cunha ${ }^{4}$, Amparo Gonçalves ${ }^{5,6}$, Maria Leonor Nunes $^{6}$, Helena Oliveira ${ }^{5,6}$

${ }^{1}$ IRTA-Food Technology Programme, Finca Camps i Armet, E-17121 Monells, Girona, Spain

${ }^{2}$ National Food Institute, Technical University of Denmark, Lyngby, Denmark ${ }^{3}$ IRTA-Food Safety Programme, Finca Camps i Armet, E-17121 Monells, Girona, Spain ${ }^{4} L A Q V, \quad R E Q U I M T E$, Departamento de Ciências Químicas, Laboratório de Bromatologia e Hidrologia, Faculdade de Farmácia, Universidade do Porto, Porto, Portugal

${ }^{5}$ IPMA, I.P., Portuguese Institute for the Sea and Atmosphere, Division of Aquaculture and Upgrading, Av. Alfredo Magalhães Ramalho 6, 1495-165 Lisboa, Portugal

${ }^{6}$ CIIMAR, Interdisciplinary Centre of Marine and Environmental Research, University of Porto, Terminal de Cruzeiros do Porto de Leixões, Av. General Norton de Matos S/N, 4450-208 Matosinhos, Portugal

* Corresponding author. E-mail address: mariadolors.guardia@irta.cat (Maria Dolors Guàrdia Gasull) 


\section{Abstract}

Excessive sodium ( $\mathrm{Na}$ ) intake has been associated with high blood pressure and cardiovascular diseases. Therefore, sodium reduction is a public health challenge worldwide. The aim of this study was to develop smoked salmon with a reduced $\mathrm{Na}$ content. Sodium chloride $(\mathrm{NaCl})$ was replaced by potassium chloride $(\mathrm{KCl})$ at $25 \%$ and $50 \%$ (molar replacement) and studied in combination with two smoking procedures (natural wood and liquid smoke) as well as two smoking temperatures (18-19ㄷ or 56 C). Smoked salmon samples were characterized by physicochemical, sensory and microbiological analyses. No major differences were observed regarding physicochemical properties in the studied treatments. Smoked samples with $50 \%$ of $\mathrm{NaCl}$ replaced by $\mathrm{KCl}$ were slightly more bitter than those with $25 \%$ whereas samples with $25 \%$ of replacement did not show differences to those with non-reduced $\mathrm{Na}$ content ( $5 \mathrm{~g}$ of added $\mathrm{NaCl}$ per $100 \mathrm{~g}$ of salmon). Molar Na:K ratio decreased from 4,3 in controls to 1,4 and 0,6 in samples with a $\mathrm{NaCl}$ reduction level of $25 \%$ and $50 \%$ respectively. Microbiological assessment indicates that 2-week shelf-life would be appropriate and safe in terms of accomplishment of the EU regulation, taking into account foreseeable storage temperatures (up to $8 \stackrel{\circ}{ } \mathrm{C}$ ). Thus, it is possible to achieve a reduction of $25-50 \%$ of $\mathrm{NaCl}$ in smoked salmon by replacing $\mathrm{NaCl}$ by $\mathrm{KCl}$ and considerer this product as a "source" of K.

Keywords: Sodium reduction, potassium chloride, smoked salmon, food safety, food quality. 


\section{Introduction}

In most European countries, the range of salt intake is 7 to 12 grams per day and it is usually higher for men than for women (EC, 2012). This consumption corresponds to a daily sodium intake of 2.8-4.8 $\mathrm{g}$. Excessive $\mathrm{Na}$ intake is one of the main risk factors for cardiovascular diseases, such as coronary heart disease and stroke, that represent a serious public health problem. Thus, the World Health Organization and the European Food Safety Authority have recommended a salt intake lower than $5 \mathrm{~g}$ ( $2 \mathrm{~g}$ of sodium) per day and the governments across Europe are adopting strategies to reduce $\mathrm{Na}$ intake (WHO, 2018; EFSA NDA Panel, 2019). Moreover, the number of products with reduced $\mathrm{Na}$ content has increased in the market during the last years, as consumers demand for healthier products has increased significantly. A reformulation of seafood products is interesting to make them healthier and this is most relevant as many countries attempt to increase the daily consumption of fish products. Many saltreducing methods have been proposed for different food categories (direct $\mathrm{NaCl}$ reduction, substitution by other salts and/or ingredients, changes in processing techniques) (Mitchell, 2019). Salt substitution is a big challenge since it is an essential ingredient in many food products and has many important functions: decreasing the water activity $\left(a_{w}\right)$, contributing to the microbial safety and shelf life, increasing the water-holding capacity, and improving sensory attributes including taste and texture of seafood (Pedro and Nunes, 2019).

Several studies have been published on technological feasibility of sodium reduction in several processed fish products and its impact on quality traits (Rodrigues et al., 2005, Fuentes et al., 2012, Osheba 2013, Rizo et al., 2017a, b, Giese et al., 2019). The most 
common approach is the partial replacement of $\mathrm{NaCl}$ by other salts (i.e. $\mathrm{KCl}, \mathrm{CaCl}_{2}$, $\mathrm{MgCl}_{2}, \mathrm{~K}$-lactate, etc.). Among them, $\mathrm{KCl}$ is considered the best substitute of $\mathrm{NaCl}$ because it allows obtaining similar functional properties and an equivalent antimicrobial effect when $\mathrm{NaCl}$ is replaced by $\mathrm{KCl}$ equimolarly using an algorithm for $\mathrm{NaCl}$ replacement (Pelroyet al., 1985; Bidlas and Lambert, 2008; Fuentes et al., 2011; Rizo et al., 2017a, b).

However, one of the major drawbacks of using $\mathrm{KCl}$ is its bitter taste (Askar et al., 1994, Cenapec et al., 2017; Giese et al., 2019). Thus, its use is limited to $50 \%$ substitution of the salt usually used in many seafood products, as observed by Martínez-Alvarez et al. (2005) and Rodrigues et al. (2005) that replaced $50 \%$ of $\mathrm{NaCl}$ by $\mathrm{KCl}$ and low concentrations of $\mathrm{CaCl}_{2}$ and $\mathrm{MgCl}_{2}$ in salted cod. Other authors also replaced successfully up to $50 \%$ of $\mathrm{NaCl}$ by $\mathrm{KCl}$ in smoked sea bass and smoke-flavoured trout (Fuentes et al., 2010; Rizo et al., 2017b). Osheha et al. (2013) found that the substitution of $\mathrm{NaCl}$ by $\mathrm{KCl}, \mathrm{K}$-lactate and a combination of both was limited to $40 \%$ in smoked herring. In smoked salmon, Almli et al. (2013) replaced successfully $33 \%$ of $\mathrm{NaCl}$ by $\mathrm{KCl}$. Rizo et al. (2017a) reached a Na reduction of $37.7 \%$ when using salt with $50 \% \mathrm{KCl}$ and $\mathrm{Na}$ free salt in smoked salmon. Similar results were obtained by Giese et al. (2019) for different salt substitutes ( $\mathrm{KCl}, \mathrm{K}$-lactate and other salts) when the trial was carried out under controlled laboratory conditions. However, it is important to notice that the elaboration processes and conditions were different in each study and this could explain differences in the results observed regarding the acceptable percentages of $\mathrm{NaCl}$ replacement. Nevertheless, the aforementioned works have been limited to the influence of salt replacement in fish products and no published research 
have been found studying the interaction between salt replacement and processing (smoking) conditions.

Considering the increasing demand of smoked salmon worldwide and the pressure towards reduced sodium seafood products, the aim of the present study was to develop smoked salmon with a reduced sodium content without compromising sensory quality and microbiological safety. For this purpose, the effect of salting with two levels of $\mathrm{NaCl}$ molar replacement by $\mathrm{KCl}(25 \%$ and $50 \%)$ combined with two smoking procedures (natural wood and liquid smoke) and two smoking temperatures $\left(18-19^{\circ} \mathrm{C}\right.$ or $\left.56^{\circ} \mathrm{C}\right)$ were investigated.

\section{Material and Methods}

\subsection{Smoked salmon preparation}

Gutted farmed fresh salmons (Salmo salar) from Norway were purchased $(n=40)$ at the central fish market (Mercabarna) in Barcelona (Spain). Salmons were transported to IRTA's facilities at $1-2{ }^{\circ} \mathrm{C}$ and stored for $24 \mathrm{~h}$ at $0-1{ }^{\circ} \mathrm{C}$. The weight of the gutted salmons was $3.1 \pm 0.3 \mathrm{~kg}$.

Salmons were filleted and trimmed. Salmon fillets were then weighted and the amount of $\mathrm{NaCl}$ (Enisal, Barcelona, Spain) and $\mathrm{KCl}$ (Dead Seaworks LTD, Tel-Aviv, Israel) calculated according to their weight. One fillet for each salmon was used as control treatment regarding the salt and sugar content added $(5 \mathrm{~g} \mathrm{NaCl} / 100 \mathrm{~g}$ salmon $+3,3 \mathrm{~g}$ sugar/100 g salmon), taking into account the usual practice of Spanish manufacturers) 
and the other fillet assigned to one specific treatment $(25$ and $50 \% \mathrm{NaCl}$ molar substitution by $\mathrm{KCl}$ ). Samples with $50 \%$ of $\mathrm{NaCl}$ molar substitution by $\mathrm{KCl}$ were added $0.1 \%$ of $\mathrm{KCl}$ masking aroma $(694409 \mathrm{KCl}$ masking flavouring, SYMRISE, Barcelona, Spain).

Salting was done by rubbing the salt-sugar (Azucarera, Barcelona, Spain) mixture on both sides of salmon fillets and then they were dry-salted during $24 \mathrm{~h}$ at $1{ }^{\circ} \mathrm{C}$. After this step, the salmon fillets were washed with tap water. Excess of water was removed using of draining and drying with cellulose towel. Salmon fillets were subjected to a dry-ageing process for $24 \mathrm{~h}$ at $1{ }^{\circ} \mathrm{C}$ with ventilation (relative humidity $75-85 \%$ and air speed $1.5 \mathrm{~m} / \mathrm{s}$ ). Afterwards, the samples were allocated to each smoking process (natural-wood or liquid; cold or hot smoking). Smoking with natural-wood (beechwood) was carried out by using an electrical oven (DOLESCHAL Unimatic, Salzburg, Austria). Cold smoking was performed during $4 \mathrm{~h}$ at $18-19^{\circ} \mathrm{C}$ with relative humidity of $65-75 \%$. The hot smoking process was carried out in two steps: the first one lasted $7 \mathrm{~min}$ at 56 ${ }^{\circ} \mathrm{C}$ (oven pre-heated at $56{ }^{\circ} \mathrm{C}$; relative humidity $15-25 \%$ ) and then, $3 \mathrm{~h}$ and $53 \mathrm{~min}$ at $18-19{ }^{\circ} \mathrm{C}$ and relative humidity $65-75 \%$. Smoking with liquid smoke (Smokez Supreme C\&A; Red Arrow International LLC, Manitowoc, USA) was carried out by dipping the salmon fillets into a solution of 1:2 (liquid smoke:water) for 20-25 sec. Then, the salmon fillets were allocated to cold or hot smoking treatments as those smoked with natural wood. After smoking, each fillet was cooled and vacuum-packed in plastic bags of PA/PE (oxygen permeability of $50 \mathrm{~cm}^{3} / \mathrm{m}^{2} / 24 \mathrm{~h}$ and a low water vapor permeability of $2.8 \mathrm{~g} / \mathrm{m}^{2} / 24 \mathrm{~h}$; Sistemvac, Estudi Graf S.A., Girona, Spain) separately and stored at 1 ${ }^{\circ} \mathrm{C}$ until sampling for microbiological analysis after 15 days of storage. Fillets were then 
frozen and kept until further analyses. Twenty-four hours before performing physicochemical analyses including $\mathrm{Na}, \mathrm{K}, \mathrm{pH}$, water activity, phenol, instrumental colour and texture and sensory evaluation, samples were thawed at $1-2{ }^{\circ} \mathrm{C}$. In total, 8 treatments ( 5 salmons each one) treatment) were tested.

\subsection{Physicochemical analyses}

\subsubsection{Water activity $\left(\mathrm{a}_{\mathrm{w}}\right)$, water content and $\mathrm{pH}$}

Water activity $\left(\mathrm{a}_{\mathrm{w}}\right)$ measurement was carried out at $25 \stackrel{\circ}{ } \mathrm{C}$ with a Novasina AW SPRINTTH 500 instrument (Axair Ltd., Pfaffikon, Switzerland). The water content ( $\mathrm{kg} \mathrm{H}_{2} \mathrm{O} / \mathrm{kg}$ product) of the samples was determined by drying at $103 \pm 2{ }^{\circ} \mathrm{C}$ until reaching a constant weight (ISO 1442: 1997).

The $\mathrm{pH}$ was measured in three fillets per treatment with a solid glass electrode (Crison 52-32) and a portable $\mathrm{pH}$ meter (Crison $\mathrm{PH} 25)$, both from Crison Instruments, SA (Alella, Spain). Results per sample were calculated as the average of three measurements per each fillet.

\subsubsection{Sodium $(\mathrm{Na})$ and potassium $(\mathrm{K})$}

The $\mathrm{Na}$ and $\mathrm{K}$ contents were determined by flame atomic absorption spectrophotometry (Spectr AA 55B spectrophotometer, Varian, Palo Alto, CA, USA) with a background deuterium correction based on the method described by Jorhem (2000). The concentrations were calculated using linear calibration obtained from absorbance measurements of five different concentrations of standard solutions: $\mathrm{NaNO}_{3}$ and $\mathrm{KNO}_{3}$ (dissolved in $0.5 \mathrm{M} \mathrm{HNO}_{3}$ ). $\mathrm{Na}$ and $\mathrm{K}$ analyses were performed in 40 samples. 
A nutritional contribution (NC) of the smoked salmon was calculated based on $\mathrm{Na}$ and $\mathrm{K}$ contents per $100 \mathrm{~g}$ and the dietary reference values recommended for adults (men and women) by the European Food Safety Authority $(3500$ mg/day for K (EFSA NDA Panel, 2016); and $2000 \mathrm{mg} /$ day for Na (EFSA NDA Panel, 2019)), according to the following formula: $\mathrm{NC}(\%)=100 \times(\mathrm{C} \times \mathrm{M}) / \mathrm{Al} *$, where $\mathrm{C}=$ mean concentration of the mineral in $\mathrm{mg} / \mathrm{kg} ; \mathrm{M}=$ typical meal portion $(0.10 \mathrm{~kg})$; and $\mathrm{Al}=$ adequate intake (mg/day).

\subsubsection{Phenol and lactic acid concentration}

Smoke intensity measured as the concentration of phenol was determined by a spectrophotometric method (Cardinal et al., 2004). In brief, phenols were extracted from smoked salmon by using an alcoholic solution. In an alkaline environment and in the presence of potassium ferri-cyanide a colour reaction developed by means of amino-4-antipyrine. After extraction with chloroform, this colour development was measured spectrophotometrically at $455 \mathrm{~nm}$.

Lactic acid concentration was determined by high-performance liquid chromatography/UV (HPLC-UV) method. Briefly, samples were extracted with hexane after a previous treatment with ethanol then derivatized with with O-(4- nitrobenzil)N,N'diisopropylisourea and analysed by HPLC-UV - Jasco equipped with a PU-1580 quaternary pump, a Jasco AS-950 automatic sampler with a $10 \mu \mathrm{L}$ loop and UV detector (Jasco, Japan) according to Cunha et al., (2001). The limit of detection was $0.056 \mathrm{~g} / \mathrm{kg}$. 


\subsubsection{Instrumental colour}

Colour measurements were carried out using a Minolta CR-400 colorimeter (AQUATEKNICA S.A., Valencia, Spain) in the CIE-LAB colour space (Commission Internationale de l'Eclairage, 1976) using illuminant C, $2^{\circ}$ viewing angle and an aperture diameter of $8 \mathrm{~mm}$. The colour space system used was CIE-L*a*b* to represent the following parameters: $L^{*}$ value $(0$, dark; 100 , light $), a^{*}$ value $(+$, red; -, green), and $b^{*}$ value $\left(+\right.$, yellow; -, blue). Lightness $\left(L^{*}\right)$, redness $\left(a^{*}\right)$, and yellowness $\left(b^{*}\right)$ were recorded. The final value per sample (salmon fillet) was presented as the mean of four measurements undertaken on the fillet surface.

\subsubsection{Instrumental texture}

A uniaxial compression test was carried out using a cross-head speed of $1 \mathrm{~mm} / \mathrm{s}$ and a compression distance of $4 \mathrm{~mm}$ (as from the probe contacted with the surface area of the sample). All measurements on fillets were undertaken using a steel $18 \mathrm{~mm}$ diameter sphere. This device was selected in order to simulate a human finger. The final value per sample (salmon fillet) was presented as the mean of four measurements (sampling points on the surface; Figure 1). Measurements were carried out using a TA.Hdplus texture analyser (Stable Micro Systems, Surrey, UK) and the following parameters were obtained from the Force-time curves: force, area and slope.

Figure 1. Sampling points for instrumental texture analysis 


\subsection{Sensory analysis}

Six selected and trained assessors (ASTM, 1981; ISO 8586-1, 1993 and ISO 8586-2, 1994) with a minimum of three years of experience in tasting smoked salmon undertook the sensory analysis on $3 \mathrm{~mm}$ slices of smoked salmon. The generation of the descriptors was carried out by open discussion and consensus using two samples of each treatment in two previous sessions.

The descriptors retained, among those usually used for smoked salmon evaluation at IRTA panel, were: orange colour (intensity of the colour of unprocessed salmon), cooked colour (score of the intensity of pink colour characteristic of cooked salmon), intensity of odour (score of the overall odour), smoked odour (score of the intensity of smoke), raw-salted salmon odour (score of the intensity of the fresh salted salmon odour), flavour intensity (score of the overall flavour), sweetness (basic taste sensation elicited by sugar), saltiness (basic taste sensation elicited by $\mathrm{NaCl}$ ), bitterness (basic taste sensation elicited by $\mathrm{KCl}$ ), smoked flavour (score of the intensity of smoke perceived in the mouth), after-taste (intensity of flavour that the sample leaves in the mouth after swallowing it mainly related with $\mathrm{KCl}$ ), hardness (force required to bite through the sample), crumbliness (textural property characterised by the ease with which a sample can be separated into smaller particles during chewing), pastiness (textural property characterised by flour-water paste). A non-structured scoring scale was used, where 0 and 10 meant respectively the absence and the high intensity of the descriptor. Sensory evaluation was undertaken in 24 sessions where each taster assessed one control sample and its counterpart in each session. Samples were coded 
with three random numbers and presented to the assessors balancing the first-order and the carry-over effects according to MacFie, Bratchell, Greenhoff, and Vallis (1989).

\subsection{Microbiological analyses}

The presence of Listeria monocytogenes was investigated from $25 \mathrm{~g}$ of smoked salmon enriched in HALF FRASER BROTH $(225 \mathrm{ml})$ for $28 \mathrm{~h}$ at $37^{\circ} \mathrm{C}$. The PrepSEQ ${ }^{\circledR}$ Rapid Spin Sample PrepKit- Extra Clean \& Bead Beating (Thermo Fisher Scientific Inc., Waltham, Massachusetts, USA) was used to extract the DNA from each sample after enrichment, which was analysed by real-time PCR using the MicroSEQ ${ }^{\circledR}$ Listeria monocytogenes detection kit (Thermo Fisher Scientific Inc.). This protocol is validated by Association Française de Normalisation (AFNOR) in different food matrices including smoked salmon. Lactic acid bacteria (LAB) were enumerated as described in the standard ISO 15214 (2008), i.e. by pour-plating the appropriate decimal dilution of the sample (made with physiological saline solution; $0.85 \% \mathrm{NaCl}$ ) in MRS agar with $\mathrm{pH} 5.7$, and incubated at $30{ }^{\circ} \mathrm{C}$ for $72 \mathrm{~h}$ under anaerobiosis (in a $2.5 \mathrm{~L}$ jars with 1 sachet AnaeroPack ${ }^{\mathrm{TM}}$-Anaero Anaerobic Gas Generator, Thermo Fisher Scientific Inc.). Analyses were carried out by sampling three different portions from each fillet (10 g of mixture) and three fillets per treatment were sampled. Analyses were carried out after 15 days of storage at $1^{\circ} \mathrm{C}$. 


\subsection{Data analysis and predictive modelling}

In order to assess the effect of smoking process and salt treatment on the physicochemical and sensory traits of smoked salmon, the analysis of variance was performed with the General Linear Model (GLM) procedure of the SAS statistical package (Statistical Analysis System [SAS] 9.4, 2019). The model included as fixed effects the smoking process, salt treatment and salmon nested within smoking process. For the sensory attributes, the average scores of the panel for each salmon fillet were used. The interaction between treatments was tested and dropped from the model since it was not significant. Statistical significance was considered at $p<0.05$ for all analyses (Zar, 2010).

Since lactic acid bacteria and L. monocytogenes were both below their limits of detection limit, statistical analysis of the results was not possible. Instead, the predictive modelling approach was used to assess the behaviour of these microorganisms, as recognised by the Regulation (EC) 2073/2005 (European Commission, 2005). Potential growth of $L A B$ and L. monocytogenes was predicted for the different treatments of smoked salmon.

Predictions relied on smoked salmon product characteristics $(\mathrm{pH}$, phenol and water phase concentrations of salt and lactic acid) as model input (independent variables). Other independent variables included the initial concentrations of $L A B$ and $L$. monocytogenes assumed to be $1 \mathrm{cfu} / \mathrm{g}$ (Mejlholm et al., 2015). Besides the storage temperature applied in the present experiment $\left(1^{\circ} \mathrm{C}\right)$, higher temperatures were also assessed to account for foreseeable storage conditions during smoked salmon storage, i.e. $5{ }^{\circ} \mathrm{C}$ and $8{ }^{\circ} \mathrm{C}$ gathering the rage of mean temperatures found in domestic 
refrigerators in EU (EFSA BIOHAZ Panel, 2018). Predictions of the growth of LAB and L. monocytogenes were obtained by using the validated models of Mejlholm and Dalgaard (2013) for LAB and of Mejlholm and Dalgaard (2009) for L. monocytogenes. A lag time was included when predicting growth of L. monocytogenes as suggested by Mejlholm et al. (2015) for naturally contaminated seafood including smoked salmon. Predictions were obtained by models as included in the Food Spoilage and Safety Predictor software (FSSP v. 4.0; http://fssp.food.dtu.dk). The percentage of water phase salt (WPS) in the smoked salmon was calculated from the measured $a_{w}$ as described by Jørgensen et al. (2000a) and FSSP v. 4.0. For treatments where $\mathrm{NaCl}$ was substituted by $\mathrm{KCl}$ microbial growth was predicted by assuming a similar inhibiting effect of the two salts as previously shown for $L A B$ and L. monocytogenes (Larson et al. 1993; Soglia et al. 2014). The effect of smoke on growth of LAB and L. monocytogenes was exclusively predicted for salmon cold-smoked with wood, as the applied models have not been validated for other types of smoked salmon (Dalgaard and Mejlholm, 2019).

The output of the model included in the FSSP v. 4.0 is the cell concentrations (log $\mathrm{cfu} / \mathrm{g}$ ) during storage, including the time in days required for LAB to grow $7 \mathrm{Log} \mathrm{cfu} / \mathrm{g}$ from 1 to $10^{7} \mathrm{cfu} / \mathrm{g}$ and the time required for L. monocytogenes to grow 2 Log cfu/g from 1 to $100 \mathrm{cfu} / \mathrm{g}$.

\section{Results and Discussion}

\subsection{Physicochemical analyses}

\subsubsection{Water activity $\left(\mathrm{a}_{\mathrm{w}}\right)$, water content and $\mathrm{pH}$}


No significant effects $(p>0.05)$ of salt substitution on $a_{w}$, water content and $p H$ were observed (Table 1). Similarly, other studies found the same result (Osheba et al. 2013; Rizo et al., 2017a,b; Giese et al., 2019). However, Fuentes et al. (2012) observed that $\mathrm{pH}$ of control samples was significantly higher than those with $50 \%$ substitution of $\mathrm{NaCl}$ by $\mathrm{KCl}$ in smoked sea bass.

Regarding the smoking process (Table 2), hot smoking with wood showed a significant lower water content than cold smoking with wood $(p<0.05)$. This decrease of $2.3 \%$ in the water content of hot smoked samples with wood could be due to partial dehydration during the smoking process and subsequent changes in the wet weight of the fillets. Industrial specifications for "smoked finished products" generally recommend a water content in the fish flesh of less than 65\% (Cardinal et al., 2001). The values obtained in the present work are in agreement with these. Both cold and hot liquid smoking showed a significant lower $\mathrm{pH}$ than cold smoking with wood (Table 2). The low $\mathrm{pH}$ of the liquid smoked samples was caused by the organic acids present in the liquid smoke used (Dien, Montolalu and Berhimpon, 2019).

Table 1. Effects of salt substitution (least squares means) on physicochemical parameters.

Table 2. Effects of the smoking process (least squares means) on physicochemical parameters.

\subsubsection{Sodium $(\mathrm{Na})$ and potassium $(\mathrm{K})$}

As expected, there was a significant $\mathrm{Na}$ reduction in the samples (regardless of the smoking process) with $25 \%$ and $50 \%$ of $\mathrm{NaCl}$ replaced by $\mathrm{KCl}$ (molar substitution) 
compared to the control (mean $=26.1 \%$ and $51.3 \%$, respectively) (Table 1 ). No significant differences were observed regarding the smoking process (Table 2).

An increase of the $\mathrm{K}$ levels (mean $=15.2 \%$ and $33.3 \%$ ) was observed in the treatments with $25 \%$ and $50 \%$ of $\mathrm{NaCl}$ molar replaced by $\mathrm{KCl}$, respectively (Table 1 ). The molar $\mathrm{Na} \mathrm{K}$ ratio, which is positively associated with blood pressure and is a predictor of cardiovascular risk, decreased from 4.3 (mean value) in samples produced with the usual $\mathrm{NaCl}$ content to 1.4 and 0.6 (mean values) in samples prepared with $25 \%$ and $50 \%$ of $\mathrm{NaCl}$ molar replaced by $\mathrm{KCl}$, respectively. These lower ratios observed in samples prepared with reduced Na levels are closer or in line with the World Health Organisation (WHO) that recommended Na:K ratio (s1) (O'Halloran et al., 2016). Thus, the molar replacements of $\mathrm{NaCl}$ by $\mathrm{KCl}(25 \%$ and $50 \%)$ in the preparation of smoked salmon is expected to have benefits on consumers' health, and therefore is an opportunity to improve the smoked salmon formulations.

On the other hand, $100 \mathrm{~g}$ of smoked salmon with reduced $\mathrm{NaCl}$ levels ( $25 \%$ and $50 \%$ ) would contribute to $38.0 \%$ and $25.1 \%$ of the adequate daily intake of $\mathrm{Na}$ for adults, respectively. These values correspond to $1.9 \mathrm{~g}$ and $1.3 \mathrm{~g}$ of salt, respectively and thus are below the limit value recommended by EFSA ( $\approx 5 \mathrm{~g}$ of salt/day) (EFSA NDA Panel, 2019). In terms of $\mathrm{K}$, the nutritional contribution of the samples with a $\mathrm{NaCl}$ reduction of $25 \%$ and $50 \%$ is $26.3 \%$ and $43.6 \%$, respectively. Thus, smoked salmon produced with $50 \%$ of $\mathrm{NaCl}$ replaced by $\mathrm{KCl}$ is a "source of $\mathrm{K}$ " according the definition of this claim (Regulation (EU) 1169/2011, Annex XIII), which is essential mainly for supporting blood pressure, cardiovascular health, bone strength, and muscle strength (EFSA NDA Panel, 2016). 


\subsubsection{Instrumental colour and texture}

Significant differences resulting from the salt substitution were observed in the colour parameters (Table 1). The a* value of the batch with $25 \%$ substitution was significantly higher than the control $(p<0.05)$. Giese et al. (2019) observed some significant differences during storage between reduced sodium samples (50\%) and the reference samples at different times for smoked salmon. However, the significance of these differences changed over time and no clear trend was observed. In the same study, no significant differences were observed for a herring product. For smoke-flavoured trout, Rizo et al. (2017b) found no significant differences when $50 \%$ of $\mathrm{NaCl}$ was replaced by $\mathrm{KCl}$ compared to without substitution.

In addition, the smoking process (Table 2 ) had a significant effect on $a^{*}$ and $b^{*}$ values. Cold liquid smoked samples presented a significantly lower a* value than those of hot smoked with wood $(p<0.05)$ that presented the highest values. Regarding $b^{*}$ values, hot liquid smoking showed a significant higher value than cold liquid smoking and cold smoking with wood. Therefore, these samples presented a more yellowish tone. Huong (2014) also found that smoked mackerel using commercial liquid smoke flavourings was more yellowish than the wood smoked mackerel.

No significant effect of both salt substitution level and smoking process (Tables 1 and 2) were observed on the instrumental texture parameters recorded ( $p>0.05)$. Similarly, no significant differences have been found in other studies (Rizo et al. 2017a, b; Giese et al., 2019) that replaced $\mathrm{NaCl}$ by $\mathrm{KCl}$, except for chewiness in smoked trout. These results could be partially explained because the thermal treatments were selected to have a minimal impact on the texture on surface. 


\subsection{Sensory Analysis}

Significant differences in odour intensity, smoked odour, raw-salted salmon odour, bitter taste, after-taste flavour and hardness due to salt substitution were observed (Figure 2). Regarding the effect of smoking, differences were significant for orange colour, odour intensity, smoked odour, raw-salted salmon odour, flavour intensity, smoked flavour and pastiness (Figure 3).

No significant differences between control samples and those with $25 \% \mathrm{NaCl}$ substitution were observed for most of the evaluated attributes. The only attribute for which a significant difference was observed was smoked odour. However, this difference was small and the impact on the overall sensory characteristics might be overall masked by all the other descriptors. For raw-salted salmon odour, the control and $25 \%$ of salt substitution samples were scored with higher intensity with regard to those with $50 \%$ of $\mathrm{NaCl}$ substitution $(\mathrm{p}<0.05)$. Conversely, samples with $50 \%$ of $\mathrm{NaCl}$ substitution, despite having $\mathrm{KCl}$ masking aroma, were scored with higher intensity of bitter taste and after-taste flavour, which can be associated with the persistence of $\mathrm{KCl}$ bitterness as well as slightly higher intensity of hardness. The increase in bitter taste and hardness was also reported by Guàrdia et al. (2008) at levels of $40 \%$ and $50 \%$ of $\mathrm{NaCl}$ substitution by $\mathrm{KCl}$ in fermented meat products. Almli and Hersleth (2013), who studied a $1 / 3$ replacement of $\mathrm{NaCl}$ by $\mathrm{KCl}$ in cold-smoked salmon, did not find any significant differences immediately after processing in the sensory properties including bitterness and metallic flavour compared to the reference product $(3 \mathrm{~g} \mathrm{NaCl}$ added per $100 \mathrm{~g} ;$ wt\%). Furthermore, Osheba (2013) did not find any negative impact on 
appearance, odour, texture, and overall sensory acceptability of smoked herring by the partial replacement of $\mathrm{NaCl}$ by $\mathrm{KCl}$ and/or K-lactate at levels of up to $40 \%$. However, Fuentes et al. (2012) reported that the taste scores were significantly lower for smoked sea bass samples containing $>50 \% \mathrm{KCl}$.

In a consumer study by Rizo et al. (2017b), no more than $20 \%$ of participants were able to detect differences between smoke-flavoured trout salted with $50 \% \mathrm{NaCl} / 50 \% \mathrm{KCl}$ and control samples. Similarly, Giese et al. (2019) reported that consumers did not discriminate in liking between the sodium-reduced samples (2.7-3.7 $\mathrm{g} \mathrm{NaCl} / 100 \mathrm{~g})$ and the reference product $(5.2 \mathrm{~g} \mathrm{NaCl} / 100 \mathrm{~g})$.

Figure 2. Effect of salt substitution (least squares means and Root Mean Standard Error) on sensory descriptors of smoked salmon. Significant level: ${ }^{* * *}(p<0.001),{ }^{* *}(p<0.05),{ }^{*}$ $(p<0.01)$

The results from the sensory analyses of samples subjected to different smoking processes showed that the smoking temperature had minimal effect on sensory properties, regardless of whether smoking was done with wood or with liquid smoke. Only a significant decrease $(p<0.05)$ in orange colour was observed for hot-smoked samples with wood compared to cold-smoked samples. However, this decrease was not relevant ( 0.5 points) because it is considered that it would be hardly detected by a consumer.

The type of smoking affected the odour attributes, flavour intensity (in the case of cold smoking), smoked flavour and pastiness. In this respect, samples smoked using liquid smoke were scored with higher odour intensity, smoked odour and smoked flavour. In 
contrast, these samples were scored with lower intensity of raw-salted salmon odour and pastiness. Probably, the highest intensity of smoked odour and flavour masked other attributes. No significant differences between samples on salty taste were detected which agrees with that obtained by Guàrdia et al. (2008) who replaced $40 \%$ of $\mathrm{NaCl}$ by $\mathrm{KCl}$ in fermented meat products.

The results obtained in the present work, are in line with those of other authors aforementioned in the present section. However, it is important to highlight that the trial was carried out under quite different conditions testing the interaction among salt reduction, smoking temperature and smoking system, which were not significant $(p>0.05)$.

Figure 3. Effect of the smoking process (least squares means and Root Mean Standard Error) on sensory descriptors of smoked salmon. Significant level: ${ }^{* * *}(p<0.001),{ }^{* *}(p<0.05),{ }^{*}$ $(p<0.01)$

\subsection{Microbiological results and predictive modelling}

Concentrations of Listeria monocytogenes were below the limit of detection of (1 cfu in $25 \mathrm{~g}$ ) for all analysed salmon samples after 15 days at $1^{\circ} \mathrm{C}$. LAB were also below the detection limit (<100 cfu/g in surface plating), therefore, smoked salmon vacuumpacked retained high quality characteristics.

The spoilage microbiota of vacuum-packed cold-smoked salmon can be dominated by lactic acid bacteria (LAB), Enterobacteriaceae or Photobacterium spp. (Truelstrup Hansen et al. 1998; Jørgensen et al. 2000a, b). The processing environment and so- 
called in-house microbiota can have a substantial impact on the dominating product microbiota (Truesltrup Hansen and Huss, 1998). The manufacture of smoked salmon for the present trial was carried out in a pilot plant where this product is not usually processed. The manufacture was performed under very high hygienic conditions, which may be far from the conditions usually found in commercial production environment. The very high hygienic conditions could explain why LAB were below the limit of detection even at day 15 of chilled storage. Thus, there were no indications that spoilage by $L A B$ would represent a problem in the samples of smoked salmon regardless of salt composition.

Predicted growth of $L A B$ and L. monocytogenes very much depended on product temperature, $\mathrm{pH}$ and $\mathrm{a}_{\mathrm{w}}$ as the water phase concentrations of lactic acid, from endogenous origin, was similar irrespective of smoking and sodium reduction (Table 3). Furthermore, the low phenol concentrations of 2.2-2.8 ppm in wood and cold-smoked salmon had limited inhibiting effect on the predicted growth of $L A B$ and $L$. monocytogenes (Table 3). A 7-log increase in LAB concentrations was predicted to take from 62 to more than 90 days at $1^{\circ} \mathrm{C}, 20-24$ days at $5{ }^{\circ} \mathrm{C}$ and $12-14$ days at $8{ }^{\circ} \mathrm{C}$, depending on the smoking process and the sodium reduction. The predicted slow growth of $L A B$ at $1{ }^{\circ} \mathrm{C}$ could be part of the reason why these organisms were not detected when analysed after 15 days at $1{ }^{\circ} \mathrm{C}$. Although, spoilage can occur when LAB achieve 7 Log cfu/g, in many occasions higher concentrations have been reported without sensory spoilage (TruesItrup Hansen and Huss, 1998; Jørgensen et al. 2000a). On the other hand, such high concentrations of LAB in food contribute to inhibit the growth of L. monocytogenes (Mejlholm et al. 2015). For L. monocytogenes a 2-log increase in cell concentration was predicted to take more than 90 days at $1{ }^{\circ} \mathrm{C}$, from 39 
to more than 90 days at $5{ }^{\circ} \mathrm{C}$ and $13-35$ days at $8{ }^{\circ} \mathrm{C}$ (Table 3). The critical concentration for L. monocytogenes in ready-to-eat foods within the EU is $100 \mathrm{cfu} / \mathrm{g}$ (European Union Reference Laboratory for L. monocytogenes, 2019). When contaminated during processing concentrations as high as about one L. monocytogenes cell/g of smoked salmon can be observed (Mejlholm et al. 2015) and a 100-fold (2-log) increase in cell concentrations of $L$. monocytogenes determines the time for critical growth in smoked salmon. If shelf-life longer than these critical times is desired then smoked salmon need to be reformulated to become more inhibiting against the growth of $L$. monocytogenes at storage temperatures reasonably occurring during the retail and consumer storage. The studied smoked salmon showed relatively low $a_{w}$ (Tables 1, 2 and 3 ) in comparison with $a_{w}>0.97$ often reported for smoked salmon (Jørgensen et al. 2000a). This contributed to the predicted long time taken by L. monocytogenes to achieve the critical increase of 2-log units: more than 90 days at $1{ }^{\circ} \mathrm{C}$ and from 39 to more than 90 days at $5{ }^{\circ} \mathrm{C}$. Only at the storage temperature of $8{ }^{\circ} \mathrm{C}$, the critical growth occurred at a time close to the duration of the present experiment (15 days). A larger margin to ensure the compliance with the food safety microbiological criteria (Regulation (CE) 2073/2005) could be achieved by using a formulation able to stabilize the smoked salmon against growth of L. monocytogenes, even when stored at $8{ }^{\circ} \mathrm{C}$. For example, product stabilization could be achieved with the addition of natural biopreservatives based on organic acids to achieve $2400 \mathrm{ppm}$ of acetic acid/acetate in water phase (ca. $0.16 \%$ acetic acid/acetate in the product) or $1000 \mathrm{ppm}$ acetic acid/acetate in water phase $(0.07 \%$ in product) together with 15000 ppm lactic acid/lactate in water phase $(0.43 \%$ lactic acid/lactate in product). Cold-smoking with wood to achieve $15 \mathrm{ppm}$ of phenols would also allow to reduce the amount of acetic 
acid/acetate in water phase to $1400 \mathrm{ppm}$ (ca. $0.09 \%$ of acetic acid/acetate in the product) and still obtain a product stabilised against growth of L. monocytogenes. Other relevant combination of product characteristics and storage condition to prevent growth of L. monocytogenes can be predicted as explained by Dalgaard and Mejlholm (2019).

\subsection{Economical analysis}

The suggested approach to $\mathrm{Na}$ reduction exclusively involves a modification of the formulation and consequently, there is no need for any investments or changes to the manufacturing process. Thus, the only difference from an economic perspective is the cost of the ingredients. The price of $\mathrm{KCl}$ is considerably higher than that of $\mathrm{NaCl}$ and therefore, the cost of salt will be approximately 5 times higher with $25 \%$ substitution and 10 times higher with $50 \%$ substitution. However, the effect on the price of the final product will be much smaller since salt makes up a very small part of the total costs. Salt represent $1.1 \%$ of the cost of ingredients and since the cost of salmon is much higher than that of salt, the increased cost of production is estimated to be merely fractions of $1 \%$. Almli and Hersleth (2013) evaluated the consumer' willingness to pay in smoked salmon with reduced salt content. Consumers did not discriminate between salt types (with different sodium content), neither in liking nor in willingness to pay. According to the authors, the results indicate a market potential for partially salt-replaced smoked salmon. 


\section{Conclusions}

The present study has shown the feasibility of a Na reduction by the use of $\mathrm{KCl}$ as $\mathrm{NaCl}$ substitute in smoked salmon combined with temperature (cold and hot smoking) and smoking type (wood and liquid). Under the tested conditions, Na reduced samples ( $25 \%$ and $50 \%)$ showed no differences compared to the control regarding most of the physicochemical parameters and sensory properties after 2 weeks of storage at chilled temperature. Furthermore, microbiological assessment indicates that 2-week shelf-life would be appropriate and safe in terms of accomplishment of the EU regulation, taking into account foreseeable storage temperatures (up to $8 \stackrel{\circ}{\circ}$ ). Thus, the $\mathrm{NaCl}$ replacement by $\mathrm{KCl}$ (up to 50\%) can be applied in the seafood industry to reduce $\mathrm{Na}$ levels in the preparation of smoked salmon, assuring a healthier and safe product, which could be part of the global Na reduction policy in processed foods and may contribute to long-term societal health benefits. Thus, the molar replacements of $\mathrm{NaCl}$ by $\mathrm{KCl}(25 \%$ and $50 \%)$ in the preparation of smoked salmon will have benefits on consumers' health.

\section{Acknowledgments}

This work has received funding from the European Union's Horizon 2020 research and innovation programme under Grant Agreement no. 773400 (SEAFOOD ${ }^{\text {TOMORROW }}$ ). This article reflects the views only of the authors and the European Union cannot be held responsible for any use, which may be made of the information contained therein. Authors from IRTA acknowledge the funding of the CERCA Programme/Generalitat de 
Catalunya (Spain). Sara Cunha also acknowledges FCT for the IF/01616/2015 contract and the support by UIDB/50006/2020 with funding from FCT/MCTES.

\section{References}

Almli, V.L, Hersleth, M., 2013. Salt replacement and injection salting in smoked salmon evaluated from descriptive and hedonic sensory perspectives. Aquaculture International, 21, 1091-1108.

Askar, A., El-Samahy, S.K., Shehata, H.A., Tawfik, M., 1994. Pasterma and beef bouillon. The effect of substituting $\mathrm{KCl}$ and k-lactate for sodium chloride. Fleischwirtschaft International, 1, 50 .

Bidlas, E. and Lambert, R.J.W., 2008. Comparing the antimicrobial effectiveness of $\mathrm{NaCl}$ and $\mathrm{KCl}$ with a view to salt/sodium replacement. International Journal of Food Microbiology, 124, 98-102.

Cardinal, M., Knockaert, C., Torrisen, O., Sigurgidottir, S. and Morkore, T. et al., 2001. Relation of smoking parameters to the yield, color and sensory quality of smoked Atlantic salmon (Salmo salar). Food Research International, 34, 537-550.

Cardinal, M., Gunnlaugsdottir, H., Bjoernevik, M., Ouisse, A., Vallet, L.J., Leroi, F., 2004. Sensory characteristics of cold-smoked Atlantic salmon (Salmo salar) from European market and relationships with chemical, physical and microbiological measurements. Food Research International 37, 181-193.

Cepanec, K., Vugrinec, S., Cvetkovic, T., Ranilovic, J., 2017. Potassium Chloride-Based Salt Substitutes: A Critical Review with a Focus on the Patent Literature. Comprehensive Reviews in Food Science and Food Safety, 16, 881-894. 
Cunha, S. C., Ferreira, I.M.P.L.V.O., Fernandes, José, O., Faria, M.A., Beatriz, M., Oliveira, P.P. and Ferreira, M.A., 2001. Determination of lactic, acetic, succinic and citric acids in table olives by HPLC/UV. Journal of Liquid Chromatography \& Related Technologies, 24:7,1029-1038.

Dalgaard, P., Mejlholm, O., 2019. Modelling growth of Listeria and lactic acid bacteria in food environments, in: Foodborne Bacterial Pathogenes, ed A. Bridier (New York, NY: Springer), 1918, 247-264.

Dien, H.A., Montolalu, R.I., Berhimpon, S., 2019. Liquid smoke inhibits growth of pathogenic and histamine forming bacteria on skipjack fillets. IOP Conference Series: Earth and Environmental Science, Volume 278, conference 1.

European Union Reference Laboratory for Listeria monocytogenes.Technical guidande document for conducting shelf-life studies on Listeria monocytogenes in ready-to-eat foods Version 3 of 6 June 2014 - Amendment 1 of 21 February 2019. Available at: https://ec.europa.eu/food/sites/food/files/safety/docs/biosafety_fh_mc_tech-guidedoc_listeria-in-rte-foods_en.pdf European Commission (2012) Commission Regulation (EU) No 432/2012 of 16 May 2012 establishing a list of permitted health claims made on foods, other than those referring to the reduction of disease risk and to children's development and health. Official Journal of the European Union, L 136, 1.

EFSA BIOHAZ Panel (EFSA Panel on Biological Hazards), Ricci, A., Allende, A., Bolton, D., Chemaly, M., Davies, R., Fernández Escámez, P.S., Gironés, R., Herman, L., Koutsoumanis, K., Nørrung, B., Robertson, L., Ru, G., Sanaa, M., Simmons, M., Skandamis, P., Snary, E., Speybroeck, N., Ter Kuile, B., Threlfall, J., Wahlström, H., 
Takkinen, J., Wagner, M., Arcella, D., Da Silva Felicio, M.T., Georgiadis, M., Messens, W., Lindqvist, R., 2018. Scientific Opinion on the Listeria monocytogenes contamination of ready-to-eat foods and the risk for human health in the EU. EFSA Journal, 16(1), 5134-5307.

EFSA NDA Panel (EFSA Panel on Dietetic Products, Nutrition and Allergies), Turck, D., Bresson, J.-L., Burlingame B, Dean, T., Fairweather-Tait, S., Heinonen, M., Hirsch-Ernst, K.I., Mangelsdorf, I., McArdle, H., Neuh€auser-Berthold, M., Nowicka, G., Pentieva, K., Sanz, Y., Siani, A., Sjödin, A., Stern, M., Tomé, D., Van Loveren, H., Vinceti, M., Illatts, P., Aggett, P., Martin, A., Przyrembel, H., Brönstrup, A., Ciok, J., Gómez Ruiz, J.A., de Sesmaisons-Lecarré, A., Naska, A., 2016. Scientific opinion on dietary reference values for potassium. EFSA Journal, 14, 4592-4648.

EFSA NDA Panel (EFSA Panel on Nutrition, Novel Foods and Food Allergens),Turck D, Castenmiller J, de Henauw S, Hirsch-Ernst K-I, Kearney J, Knutsen HK, Maciuk A, Mangelsdorf I,McArdle HJ, Pelaez C, Pentieva K, Siani A, Thies F, Tsabouri S, Vinceti M, Aggett P, Fairweather-Tait S,Martin A, Przyrembel H, Ciccolallo L, de SesmaisonsLecarré A, Martinez SV, Martino L, Naska A, 2019. Scientific opinion on dietary reference values for sodium. EFSA Journal, 17, 5778-5869.

Fuentes A., Fernández-Segovia I., Serra J.A., Barat J.M., 2010. Development of a smoked sea bass product with partial sodium replacement. LWT Food Science Technology, 43, 1426-1433

Fuentes A., Fernández-Segovia I., Barat J.M., Serra J.A., 2011. Influence of sodium replacement and packaging on quality and shelf life of smoked sea bass (Dicentrarchus labrax L.). LWT Food Science and Technology, 44, 917-923. 
Fuentes A., Fernández-Segovia I., Serra J.A., Barat J.M., 2012. Effect of partial sodium replacement on physicochemical parameters of smoked sea bass during storage. Food Science Technology International, 18, 207-217.

Giese, E., Meyer, C., Ostermeyer, U., Lehmann, I., Fritsche, J., 2019. Sodium reduction in selected fish products by means of salt substitutes. European Food Research and Technology, 245, 1651-1664.

Guàrdia, M.D., Guerrero, L., Gelabert, J., Gou, P., Arnau, J., 2008. Sensory characterisation and consumer acceptability of small calibre fermented sausages with $50 \%$ substitution of $\mathrm{NaCl}$ by mixtures of $\mathrm{KCl}$ and potassium lactate. Meat Science 80 , $1225-1230$.

Huong, D.T.T., 2014. The effect of smoking methods on the quality of smoked Mackerel. United Nations University Fisheries Training Programme, Iceland [final project]. http://www.unuftp.is/static/fellows/document/huong13prf.pdf International Organization for Standardization [ISO] 1442, 1997. Determination of moisture content. Geneva: International Organization for Standardization.

International Organization for Standardization [ISO] 8586-1, 1993. Sensory Analysis General Guidance for the Selection, Training and Monitoring of Assessors. Part 1: Selected Assessors. Geneva: International Organization for Standardization.

International Organization for Standardization [ISO] 8586-2, 1994. Sensory Analysis General Guidance for the Selection, Training and Monitoring of Assessors. Part 2: Experts. Geneva: International Organization for Standardization. 
Larson, A., Johnson, E.A., Nelson, J. H., 1993. Behaviour of Listeria monocytogenes and Salmonella Heidelberg in rennet whey containing added sodium and/or potassium chloride. Journal of Food Protection, 56, 385-389.

Jorhem, L., 2000. Determination of metals in food by atomic absorption spectrometry after dry ashing: NMKL collaborative study. Journal of AOAC International. 2000, 83, 1204-1211.

Jørgensen, L.V., Dalgaard, P., Huss, H.H., 2000a. Multiple compound quality index for cold-smoked salmon (Salmo salar) developed by multivariate regression of biogenic amines and pH. Journal of Agriculture and Food Chemistry, 48, 2448-2453.

Jørgensen, L.V., Huss, H.H., Dalgaard, P., 2000b. The effect of biogenic amine production by single microbiological cultures and metabiosis on cold-smoked salmon. Journal of Applied Microbiology, 89, 920-934.

MacFie, H. J., Bratchell, N., Greenhoff, K., Vallis, L. V., 1989. Designs to balance the effect of order of presentation and first-order carry-over effects in hall tests. Journal of Sensory Studies, 4, 129-148.

Martínez-Alvarez, O, Borderías, A.J., Gómez-Guillén, M.C., 2005. Sodium replacement in the cod (Gadus morhua) muscle salting process. Food Chemistry, 93, 125-133.

Mejlholm, O., Dalgaard, P., 2009. Development and validation of an extensive growth and growth boundary model for Listeria monocytogenes in lightly preserved and readyto-eat shrimp. Journal of Food Protection, 72, 2132-2143. 
Mejlholm, O., Dalgaard, P., 2013. Development and validation of an extensive growth and growth boundary model for psychrotolerant Lactobacillus spp. in seafood and meat products. International Journal of Food Microbiology, 167, 244-260.

Mejlholm, O., Bøknæs, N., Dalgaard, P., 2015. Development and validation of a stochastic model for potential growth of Listeria monocytogenes in naturally contaminated lightly preserved seafood. Food Microbiology, 45, 276-289.

Mitchell H.L., 2019. Alternative ingredients to sodium chloride. Reducing salt in seafood products. Eds. Beeren, C., Groves, K., and Titoria, P.M. In Reducing salt in foods. Woodhead Publishing Limited, Cambridge, 113-128.

O’Halloran, S.A., Grimes, C.A., Lacy, K.E., Campbell K.J., Nowson, C.A., 2016. Dietary intake and sources of potassium and the relationship to dietary sodium in a sample of Australian pre-school children. Nutrients 8, 496.

Osheba, A.S., 2013. Technological Attempts for production of low sodium smoked herring fish. Advance Journal of Food Science and Technology, 5(6), 695-706.

Pedro, S. and Nunes, M. L., 2019. Reducing salt in seafood products. Eds. Beeren, C., Groves, K., and Titoria, P.M. In Reducing salt in foods. Woodhead Publishing Limited, Cambridge, 185-211.

Rizo, A., Fuentes, A., Barat, J.M., Fernández-Segovia, I., 2017a. Development of a novel smoke-flavoured salmon product by sodium replacement using water vapour permeable bags. Journal of the Science of Food and Agriculture, 98(7), 2721-2728. 
Rizo, A., Fuentes, A., Fernández-Segovia, I., Barat, J.M., 2017b. Development of a novel smoke-flavoured trout product: An approach to sodium reduction and shelf life assessment. Journal of Food Engineering, 211, 22-29.

Rodrigues, M.J., Ho P., López-Caballero, M.E., Bandarra, N.M., Nunes, M.L., 2005. Chemical, microbiological, and sensory quality of cod products salted in different brines. Journal Food Science, 70:M1-M6.

Statistical Analysis System [SAS] (2019).Statistical Analysis System Release 9.4.Cary, NC: SAS Institute Inc.

Soglia, F., Petracci, M., Hudalal, S., Vannini, L., Gozzi, G., Camprini, L., Cavani, C., 2014. Partial replacement of sodium chloride with potassium choride in marinated rabbit meat. International Journal of Food Science and Technology, 49, 2184-2191.

Truesltrup Hansen, L., Huss, H.H., 1998. Comparison of the microflora isolated from spoiled cold-smoked salmon from three smokehouses. Food Research International, 31, 703-711.

Truelstrup Hansen, L., Røntved, S. D., Huss, H. H. 1998. Microbiological quality and shelf life of cold-smoked salmon from three different processing plants. Food Microbiology, 15, 137-150.

WHO (World Health Organization), 2018. Using dietary intake modelling to achieve population salt reduction. A guide to developing a country-specific salt reduction model. WHO Regional Office for Europe, Copenhagen, Denmark. 26 pp. Available at: http://www.euro.who.int/_data/assets/pdf_file/0004/365242/salt-reporteng.pdf?ua=1 
Zar, J.H., 2010. Biostatistical Analysis, fifth ed. Prentice Hall Pearson, Upper Saddle River,

NJ,

USA. 
Figure 1

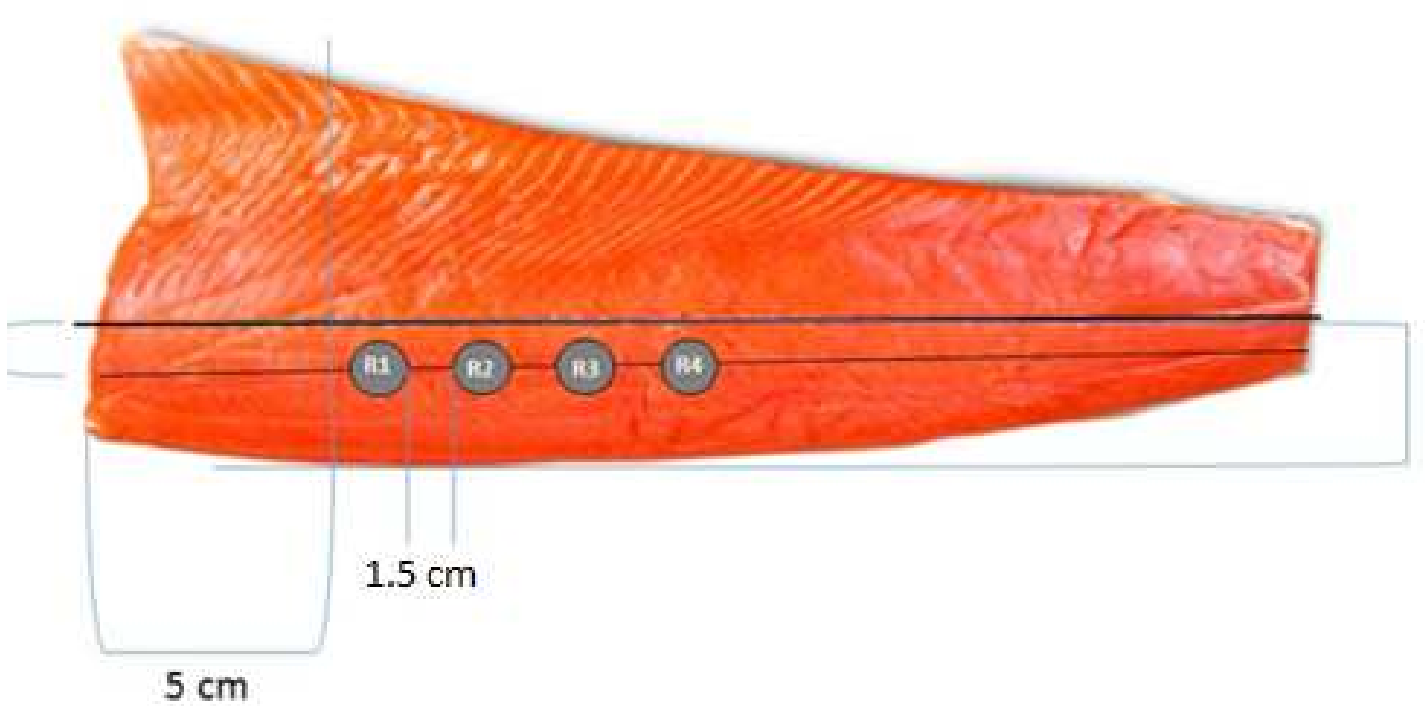




\section{Figure 2}

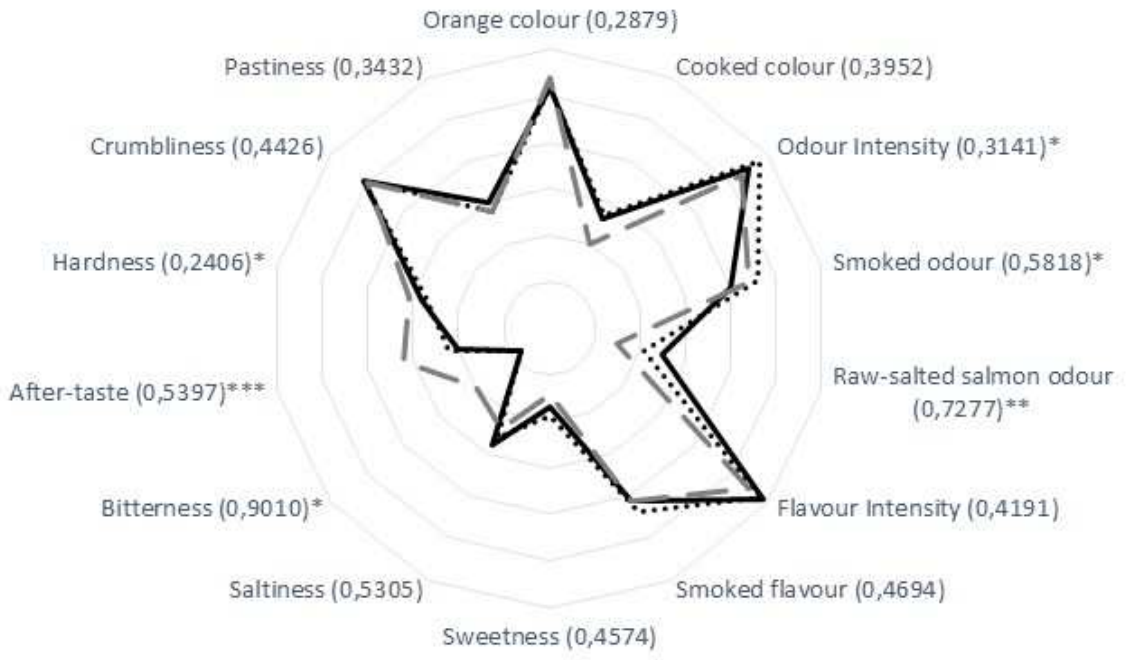

Control $\quad \cdots \cdots \cdot 25 \%$ substitution $\quad-\quad-50 \%$ substitution 
Figure 3

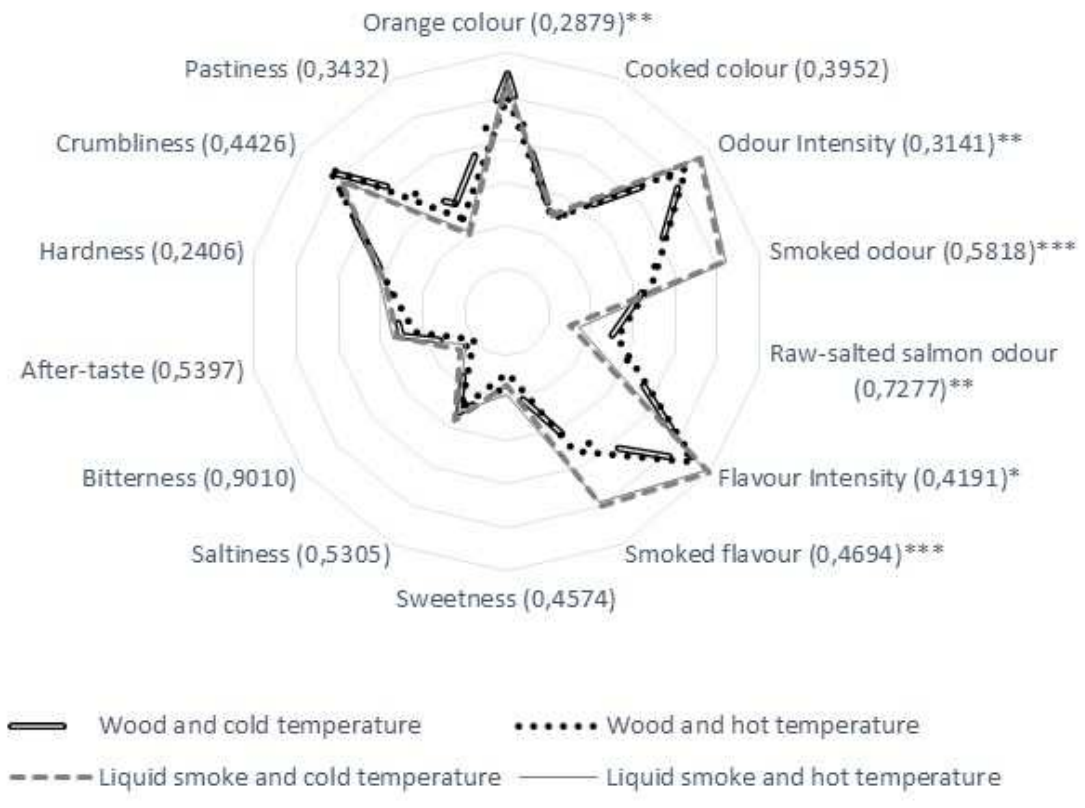


Table 1

\begin{tabular}{|c|c|c|c|c|c|}
\hline & \multicolumn{3}{|c|}{ Batch } & \multirow[b]{2}{*}{$P$ value } & \multirow[b]{2}{*}{ RMSE $^{1}$} \\
\hline & Control & $\begin{array}{c}25 \% \\
\text { substitution }\end{array}$ & $\begin{array}{c}50 \% \\
\text { substitution }\end{array}$ & & \\
\hline \multicolumn{6}{|c|}{ Physicochemical parameters } \\
\hline$a_{w}$ & 0.964 & 0.967 & 0.966 & 0.059 & 0.004 \\
\hline Water content & 61.26 & 61.65 & 60.35 & 0.429 & 1.381 \\
\hline $\mathrm{pH}$ & 5.80 & 5.80 & 5.87 & 0.219 & 0.114 \\
\hline $\mathrm{Na}(\mathrm{mg} / 100 \mathrm{~g})$ & $1054.31^{\mathrm{a}}$ & $769.76^{b}$ & $494.19^{c}$ & $<0.0001$ & 105.63 \\
\hline $\mathrm{K}(\mathrm{mg} / 100 \mathrm{~g})$ & $493.91^{c}$ & $993.79^{b}$ & $1426.04^{\mathrm{a}}$ & $<0.0001$ & 89.139 \\
\hline \multicolumn{6}{|c|}{ Instrumental colour } \\
\hline $\mathrm{L}$ & 49.67 & 47.78 & 50.01 & 0.468 & 5.160 \\
\hline a & $20.06^{\mathrm{b}}$ & $22.01^{\mathrm{a}}$ & $20.52^{\mathrm{ab}}$ & 0.019 & 2.314 \\
\hline $\mathrm{b}$ & 20.85 & 22.37 & 20.79 & 0.135 & 2.485 \\
\hline \multicolumn{6}{|c|}{ Instrumental texture } \\
\hline Force $(\mathrm{N})$ & 2.02 & 1.63 & 1.83 & 0.081 & 0.313 \\
\hline Area (g.mm) & 310.71 & 258.93 & 278.07 & 0.068 & 42.631 \\
\hline Slope $(\mathrm{g} / \mathrm{mm})$ & 70.50 & 56.04 & 64.50 & 0.104 & 12.241 \\
\hline
\end{tabular}




\begin{tabular}{|c|c|c|c|c|c|c|}
\hline & \multicolumn{4}{|c|}{ Batch } & \multirow[b]{2}{*}{$P$ value } & \multirow[b]{2}{*}{$\mathrm{RMSE}^{1}$} \\
\hline & $\begin{array}{c}\text { Cold } \\
\text { smoking } \\
\text { with wood }\end{array}$ & $\begin{array}{c}\text { Hot } \\
\text { smoking } \\
\text { with wood }\end{array}$ & $\begin{array}{l}\text { Cold liquid } \\
\text { smoking }\end{array}$ & $\begin{array}{c}\text { Hot liquid } \\
\text { smoking }\end{array}$ & & \\
\hline \multicolumn{7}{|c|}{ Physicochemical parameters } \\
\hline$a_{w}$ & 0.965 & 0.965 & 0.967 & 0.964 & 0.1660 & 0.0043 \\
\hline $\begin{array}{l}\text { Water } \\
\text { content }\end{array}$ & $62.06^{\mathrm{a}}$ & $59.77^{b}$ & $61.92^{\mathrm{ab}}$ & $60.60^{\mathrm{ab}}$ & 0.0197 & 1.3806 \\
\hline $\mathrm{pH}$ & $5.92^{\mathrm{a}}$ & $5.83^{\mathrm{ab}}$ & $5.79^{b}$ & $5.75^{\mathrm{b}}$ & 0.0003 & 0.1139 \\
\hline $\mathrm{Na}(\mathrm{mg} / 100 \mathrm{~g})$ & 779.98 & 783.39 & 728.39 & 799.95 & 0.6484 & 105.629 \\
\hline $\mathrm{K}(\mathrm{mg} / 100 \mathrm{~g})$ & 1001.64 & 1000.99 & 917.68 & 964.67 & 0.4831 & 89.139 \\
\hline \multicolumn{7}{|c|}{ Instrumental colour parameters } \\
\hline $\mathrm{L}$ & 51.01 & 50.25 & 48.26 & 47.08 & 0.0592 & 5.1599 \\
\hline a & $20.79^{\mathrm{ab}}$ & $21.93^{\mathrm{a}}$ & $19.62^{b}$ & $21.11^{\mathrm{ab}}$ & 0.0253 & 2.3135 \\
\hline $\mathrm{b}$ & $20.21^{\mathrm{b}}$ & $21.80^{\mathrm{ab}}$ & $20.46^{b}$ & $22.87^{\mathrm{a}}$ & 0.0027 & 2.4846 \\
\hline \multicolumn{7}{|c|}{ Instrumental texture parameters } \\
\hline Force (N) & 1.56 & 1.91 & 1.98 & 1.85 & 0.0883 & 0.3134 \\
\hline Area (g.mm) & 241.17 & 292.46 & 299.71 & 296.95 & 0.0574 & 42.63 \\
\hline Slope $(\mathrm{g} / \mathrm{mm})$ & 54.73 & 67.02 & 70.31 & 62.66 & 0.1169 & 12.24 \\
\hline
\end{tabular}


Table 3. Predicted growth of Listeria monocytogenes and lactic acid bacteria in vacuum-packed smoked salmon depending on product characteristics and storage temperature.

\begin{tabular}{|c|c|c|c|c|c|c|c|c|c|c|c|c|c|}
\hline \multirow{2}{*}{\multicolumn{3}{|c|}{ Smoking and sodium reduction }} & \multirow{2}{*}{\multicolumn{5}{|c|}{ Measured product characteristics ${ }^{a}$}} & \multicolumn{6}{|c|}{ Predicted growth of bacteria } \\
\hline & & & & & & & & \multirow{2}{*}{\multicolumn{3}{|c|}{$\begin{array}{c}\text { Listeria } \\
\text { monocytogenes } \\
\text { Time for 2-log } \\
\text { increase (days) } \\
\end{array}$}} & \multirow{2}{*}{\multicolumn{3}{|c|}{$\begin{array}{l}\text { Lactic acid bacteria } \\
\text { Time for 7-log } \\
\text { increase (days) }\end{array}$}} \\
\hline \multirow[t]{2}{*}{$\begin{array}{l}\text { Smoke } \\
\text { type }\end{array}$} & \multirow[t]{2}{*}{$\begin{array}{l}\text { Smoke } \\
\text { temp. }\end{array}$} & \multirow[t]{2}{*}{$\begin{array}{c}\% \mathrm{NaCl} ; \\
\% \mathrm{KCl}\end{array}$} & \multirow[t]{2}{*}{$a_{w}$} & \multirow{2}{*}{$\begin{array}{c}\% \mathrm{NaCl} \text { in } \\
\text { water phase } \\
\text { (WPS) }^{\text {b }}\end{array}$} & \multirow[t]{2}{*}{$\mathrm{pH}$} & \multirow{2}{*}{$\begin{array}{c}\text { Lactic acid in } \\
\text { water phase, } \\
\mathrm{g} / \mathrm{L}^{\mathrm{c}}\end{array}$} & \multirow[t]{2}{*}{$\begin{array}{c}\text { Phenol, } \\
\text { ppm }^{c}\end{array}$} & & & & & & \\
\hline & & & & & & & & $1^{\circ} \mathrm{C}$ & $5^{\circ} \mathrm{C}$ & $8^{\circ} \mathrm{C}$ & $1^{\circ} \mathrm{C}$ & $5^{\circ} \mathrm{C}$ & $8^{\circ} \mathrm{C}$ \\
\hline Wood & Cold & $100 ; 0$ & $\begin{array}{c}0.964 \pm \\
0.010\end{array}$ & $5.95 \pm 0.76$ & $5.92 \pm 0.21$ & & $2.2 \pm 0.5$ & $>90$ & 51 & 16 & 79 & 23 & 14 \\
\hline Wood & Cold & $75 ; 25$ & $\begin{array}{c}0.966 \pm \\
0.002\end{array}$ & $5.65 \pm 0.69$ & $5.77 \pm 0.17$ & $9.0 \pm 4.2$ & $2.8 \pm 0.9$ & $>90$ & $>90$ & 25 & 87 & 23 & 14 \\
\hline Wood & Cold & $50 ; 50$ & $\begin{array}{c}0.966 \pm \\
0.005\end{array}$ & $5.62 \pm 0.63$ & $5.87 \pm 0.32$ & & $2.4 \pm 0.3$ & $>90$ & 57 & 17 & 75 & 22 & 13 \\
\hline Wood & Hot & $100 ; 0$ & $\begin{array}{c}0.963 \pm \\
0.006\end{array}$ & $6.11 \pm 0.92$ & $5.77 \pm 0.32$ & & - & $>90$ & $>90$ & 24 & $>90$ & 24 & 14 \\
\hline Wood & Hot & $75 ; 25$ & $\begin{array}{c}0.967 \pm \\
0.006\end{array}$ & $5.43 \pm 0.85$ & $5.79 \pm 0.35$ & $8.5 \pm 3.0$ & - & $>90$ & 68 & 18 & 70 & 22 & 12 \\
\hline Wood & Hot & $50 ; 50$ & $\begin{array}{c}0.964 \pm \\
0.003\end{array}$ & $5.96 \pm 0.48$ & $5.93 \pm 0.32$ & & - & $>90$ & 41 & 14 & 72 & 22 & 13 \\
\hline Liquid & Cold & $100 ; 0$ & $\begin{array}{c}0.966 \pm \\
0.004\end{array}$ & $5.66 \pm 0.64$ & $5.75 \pm 0.31$ & & - & $>90$ & $>90$ & 23 & 81 & 22 & 13 \\
\hline Liquid & Cold & $75 ; 25$ & $\begin{array}{c}0.969 \pm \\
0.001\end{array}$ & $5.25 \pm 0.08$ & $5.85 \pm 0.25$ & $8.5 \pm 5.0$ & - & $>90$ & 45 & 14 & 62 & 20 & 12 \\
\hline Liquid & Cold & $50 ; 50$ & $\begin{array}{c}0.968 \pm \\
0.002\end{array}$ & $5.41 \pm 0.36$ & $5.90 \pm 0.27$ & & - & $>90$ & 39 & 13 & 62 & 20 & 12 \\
\hline Liquid & Hot & $100 ; 0$ & $\begin{array}{c}0.963 \pm \\
0.010\end{array}$ & $6.09 \pm 1.40$ & $5.75 \pm 0.32$ & & - & $>90$ & $>90$ & 35 & $>90$ & 24 & 14 \\
\hline Liquid & Hot & $75 ; 25$ & $\begin{array}{c}0.966 \pm \\
0.002\end{array}$ & $5.68 \pm 0.31$ & $5.73 \pm 0.30$ & $9.7 \pm 5.0$ & - & $>90$ & $>90$ & 34 & $>90$ & 22 & 13 \\
\hline Liquid & Hot & $50 ; 50$ & $\begin{array}{c}0.964 \pm \\
0.005\end{array}$ & $5.89 \pm 0.73$ & $5.75 \pm 0.44$ & & - & $>90$ & $>90$ & 34 & $>90$ & 23 & 14 \\
\hline
\end{tabular}


${ }^{a}$ Values indicate mean \pm standard deviation. ${ }^{b}$ Percentage WPS determined from measured $a_{w}$ (Jørgensen et al. 2000a). ${ }^{c}$ Determined for each combination of smoke type and temperature $(n=10-12) .{ }^{d}$ Phenol was exclusively measured for cold-smoked salmon produced with wood smoke as models to predict the effect of other types of smoking are not available. 


\section{Highlights}

- $\quad 25-50 \% \mathrm{NaCl}$ replacement by $\mathrm{KCl}$ was investigated for natural and liquid smoking procedures at $18-19$ and 56 으

- No sensory differences were observed for $25 \% \mathrm{NaCl}$ replacement by $\mathrm{KCl}$ in the four smoking treatments

- $50 \% \mathrm{NaCl}$ replacement by $\mathrm{KCl}$ resulted in a slightly more bitter product in all the smoking treatments

- Salmon with $\mathrm{KCl}$ substitution had a 2 week shelf-life when stored in refrigeration

- Salmon with $\mathrm{KCl}$ substitution could be a "source" of K

- Salmon with $\mathrm{KCl}$ substitution could be a "reduced salt content" product 


\section{Declaration of interests}

$\bigotimes$ The authors declare that they have no known competing financial interests or personal relationships that could have appeared to influence the work reported in this paper.

$\square$ The authors declare the following financial interests/personal relationships which may be considered as potential competing interests: 